\title{
Evaluation of Boulder Deposits Linked to Late Neogene Hurricane Events
}

\author{
Markes E. Johnson ${ }^{1, *}$ (1) and Jorge Ledesma-Vázquez ${ }^{2}$ \\ 1 Department of Geosciences, Williams College, Williamstown, MA 01267, USA \\ 2 Facultad de Ciencias Marinas, Universidad Autónoma de Baja California, \\ Ensenada 22800, Baja California, Mexico; ledesma@uabc.edu.mx \\ * Correspondence: mjohnson@williams.edu; Tel.: +1-413-2329
}

check for updates

Citation: Johnson, M.E.; Ledesma-Vázquez, J. Evaluation of Boulder Deposits Linked to Late Neogene Hurricane Events. J. Mar. Sci. Eng. 2021, 9, 1278. https://doi.org/ $10.3390 /$ jmse9111278

Received: 11 November 2021 Accepted: 15 November 2021 Published: 17 November 2021

Publisher's Note: MDPI stays neutral with regard to jurisdictional claims in published maps and institutional affiliations.

Copyright: (c) 2021 by the authors. Licensee MDPI, Basel, Switzerland. This article is an open access article distributed under the terms and conditions of the Creative Commons Attribution (CC BY) license (https:// creativecommons.org/licenses/by/ $4.0 /)$.
The Neogene is a globally recognized interval of geologic time that lasted from 23 until 1.8 million years ago, also divided into two geological periods: the Miocene and the Pliocene [1]. Eight contributions to this Special Issue are available for study and comparison, which span not only the Neogene but the last 1.8 million years of Earth history including the Pleistocene glacial and inter-glacial epochs followed by the Holocene beginning only 10,000 years ago. Like today, past hurricane events were responsible for the erosion of rocky shores due to the impact of storm waves and for the development of flood deposits due to heavy rainfall after big storms made landfall. The former had the potential to result in coastal boulder beds (CBDs) eroded from sea cliffs and the latter in coastal outwash deposits (CODs) derived from upland sources. Two key events are widely recorded during the Neogene, known as the Middle Miocene climatic optimum (about 15 million years ago) and subsequent Pliocene climatic optimum (between $\sim 4.5$ and 3.0 million years ago) [2]. During those peak times, the global average temperature and average sea level were higher compared to today. Major sea storms originating as subtropical depressions may have been more common on the high seas and more effective in making landfall over islands and continental shores. The survey conducted by Ruban (2019) [3] was the first contribution to this Special Issue. It reviews 21 studies almost evenly divided between the Miocene and Pliocene. All feature a mixture of boulder-size clasts exceeding $25.6 \mathrm{~cm}$ in diameter, although the original author's intent was not always explicit with the identification of a CBD related to storm activity. Indeed, some examples are attributed to a delta setting more consistent with a COD and others are interpreted as tsunami deposits. The overall relevance of the Special Issue is that the Neogene acts as a casement for a bridge head that connects the past to the present time with increased global warming inducive to expanded hurricane activity [2].

The co-editors of this Special Issue (SI) have a particular interest in Mexico's Baja California peninsula and adjacent Gulf of California (also known as the Sea of Cortez). Three contributions to the SI detail CBDs along the eastern seaboard of the peninsula within the Gulf of California [4-6]. Studies conducted on Isla San Luis Gonzaga in the upper or northern part of the Gulf [4], as well as at Puerto Escondido on the peninsula's central coast [5], relate to the erosion of andesite sea cliffs during the Holocene time. The study on Isla San Diego in the lower or southern part of the Gulf [6] deals with Pleistocene storm events that occurred approximately 125,000 years ago. A unique feature of these studies is the application of a triangular plotting system that takes into account the shape of eroded shore bounders, based on measurements in three dimensions. More perfectly spherical boulders plot near the apex of the triangle, and boulders that are more elongated in shape plot towards the lower, right corner of the triangle. Relatively few boulders derived from andesite rocky shores $[4,5]$ plot as spherical in shape, whereas the trend toward elongated boulders is notably prominent. The same is generally true of boulders derived from granodiorite rocky shores [6], which formed from the slow cooling of magma deeper within the earth's crust when compared to surface flows associated with the regionally 
more common andesite. However, the sheeted exfoliation of granodiorite typical of its natural weathering appears to have resulted in similarly shaped boulders favoring an elongated form. Another aspect of Isla San Diego includes a tail of eroded boulders observed as extending underwater from the southern end of the island for a distance of nearly $1.5 \mathrm{~km} \mathrm{[6],} \mathrm{believed} \mathrm{to} \mathrm{be} \mathrm{formed} \mathrm{under} \mathrm{the} \mathrm{influence} \mathrm{of} \mathrm{recent} \mathrm{storm} \mathrm{activity.}$

Three contributions to the SI [7-9] relate to island deposits in the North Atlantic Ocean. From the Azorean island of Santa Maria [7], comparisons are made among paired CBDs of Pliocene and Pleistocene origin exposed along the southern coast of that island. A Pleistocene CBD [8] is described from Gran Canaria in the Canary Islands. A Holocene CBD is analyzed from Leka Island at a high latitude off the coast of Norway. These Atlanticisland studies conform to the same procedures entailed in the analysis of boulder shapes as shown for the CBDs from Mexico's Gulf of California, and each pays attention to the key factor of rock density. Generally smaller in size, the cobbles and boulders at Støypet on Leka Island were eroded from low-grade chromite ore with a density of $3.32 \mathrm{~g} / \mathrm{cm}^{3}$.This reflects the highest-density rock type yet studied for its hydrological properties in a coastal setting. The basalt from the Canary and Azores registers between 2.8 and $3.0 \mathrm{~g} / \mathrm{cm}^{3}$. The density of granodiorite from Isla San Diego in the Gulf of California was found to be $2.5 \mathrm{~g} / \mathrm{cm}^{3}$ [6], whereas andesite samples from Puerto Escondido and Isla San Luis Gonzaga were found to register a density of $2.3 \mathrm{~g} / \mathrm{cm}^{3}$ or higher [4,5]. While it is routine to consider the rock density when studying the hydrology of boulders under wave attack from individual study localities, the data from multiple localities summarized in one place makes for interesting comparisons. The same amount of wave energy necessary to budge the smallest boulder at Støypet, for example, is expected to shift a boulder with significantly more volume on an igneous rocky shore elsewhere.

Last, the paper by Ruban (2020) [10], which is complimentary to his initial contribution to the SI [3], provides a path forward with examples for future studies of CBDs based on satellite reconnaissance. Such techniques will be critical in the search for additional Neogene localities with mega-clast deposits preserved in coastal settings. Where it focuses on the Middle Miocene climatic optimum and later Pliocene climatic optimum [2], this agenda is sure to prove useful as climatologists make comparisons with the past to gauge the future consequences of global warming related to the erosive power of hurricanes.

Author Contributions: The text was prepared by first author (M.E.J.) and approved by the second author (J.L.-V.). All authors have read and agreed to the published version of the manuscript.

Funding: This research received no external funding.

Acknowledgments: The guest editors for this SI wish to thank the individual authors who participated in the project for their enthusiasm and timely adherence to deadlines.

Conflicts of Interest: The authors declare no conflict of interest.

\section{References}

1. Ogg, J.G.; Ogg, G.; Gradstein, F.M. The Concise Geologic Time Scale; Cambridge University Press: Cambridge, UK, 2008; 177p.

2. Johnson, M.E. Geological Oceanography of the Pliocene Warm Period: A Review with Predictions on the Future of Global Warming. J. Mar. Sci. Eng. 2021, 9, 1210. [CrossRef]

3. Ruban, D.M. Coastal Boulder Deposits of the Neogene World: A Synopsis. J. Mar. Sci. Eng. 2019, 7, 446. [CrossRef]

4. Guardado-France, R.; Johnson, M.E.; Ledesma-Vázquez, J.; Santa Rosa-del Rio, M.A.; Herrera-Gutiérrez, Á.R. Multiphase Storm Deposits Eroded from Andesite Sea Cliffs on Isla San Luis Gonzaga (Northern Gulf of California, Mexico). J. Mar. Sci. Eng. 2020, 8, 525. [CrossRef]

5. Johnson, M.E.; Johnson, E.M.; Guardado-France, R.; Ledesma-Vázquez, J. Holocene Hurricane Deposits Eroded as Coastal Barriers from Andesite Sea Cliffs at Puerto Escondido (Baja California Sur, Mexico). J. Mar. Sci. Eng. 2020, 8, 75. [CrossRef]

6. Callahan, G.; Johnson, M.E.; Guardado-France, R.; Ledesma-Vázquez, J. Upper Pleistocene and Holocene Storm Deposits Eroded from the Granodiorite Coast on Isla San Diego (Baja California Sur, Mexico). J. Mar. Sci. Eng. 2021, 9, 555. [CrossRef]

7. Ávila, S.P.; Johnson, M.E.; Rebelo, A.C.; Baptista, L.; Melo, C.S. Comparison of Modern and Pleistocene (MIS 5e) Coastal Boulder Deposits from Santa Maria Island (Azores Archipelago, NE Atlantic Ocean). J. Mar. Sci. Eng. 2020, 8, 386. [CrossRef] 
8. Galindo, I.; Johnson, M.E.; Martín-González, E.; Romero, C.; Vegas, J.; Melo, C.S.; Ávila, S.P.; Sánchez, N. Late Pleistocene Boulder Slumps Eroded from a Basalt Shoreline at El Confital Beach on Gran Canaria (Canary Islands, Spain). J. Mar. Sci. Eng. 2021, 9, 138. [CrossRef]

9. Johnson, M.E. Holocene Boulder Beach Eroded from Chromite and Dunite Sea Cliffs at Støypet on Leka Island (Northern Norway). J. Mar. Sci. Eng. 2020, 8, 644. [CrossRef]

10. Ruban, D.A. Finding Coastal Megaclast Deposits: A Virtual Perspective. J. Mar. Sci. Eng. 2020, 8, 164. [CrossRef] 